\title{
Character Education and Development of Students' Intellectual Capital in Boarding School Student Al Furqon, Ponorogo
}

\author{
Katni $^{1}$, Anip Dwi Saputro ${ }^{2}$ \\ Muhammadiyah University of Ponorogo, East Java, Indonesia ${ }^{1,2}$ \\ $\left\{\underline{\text { katni@umpo.ac.id }}\right.$, anipdwisaputro@umpo.ac.id $\left.{ }^{2}\right\}$
}

\begin{abstract}
The development education especially higher education, both public and private, are required to develop his model to face the challenges of the times. Therefore, the function of higher education is very strategic in building a model of Islamic education and integrates between Islam and science. This research was conducted at Pesantren Al Furqon Ponorogo cooperation with the Muhammadiyah University of Ponorogo. This paper discusses the character education and development of students ' intellectual capital in boarding school students. Finally, the efforts of combining academic culture and religion should be a concern of all Muslim academics, especially on secondary higher education. This study strongly supports many socio-political situations at the moment to give a chance at the higher education of Islam in order to be thriving in creating a civilized intellectual. Student boarding school model more effective in character education and development of students ' intellectual capital so that it is capable of producing quality graduates to higher education. Student very urgent boarding school Model developed in various Islamic colleges in Indonesia map internationally.
\end{abstract}

Keywords: Character Education, Intellectual Capital, Boarding School Students

\section{Introduction}

Muslims should continue to develop the education system in accordance with the views of the Islamic world. It is important for Muslims to evaluate and develop this system in the context of education in the 21 st century. This has prompted new century thinkers, educators, and stakeholders related to proposing the idea of educational frameworks that can help students, teachers, and administrators to address the new challenges that have never happened before. [1]

Islamic higher education is essentially a place of birth of the competent religious, intellectual cadres. Here the values of Islam which are sublime as honest, responsibility, caring, zealous, religious, willing to sacrifice, critical and other positive values can be implanted, internalized and become a culture in an effort to build the intellectual capital.

Malik Fajar described the distinction between tradition education in boarding school and College; she said that the boarding school has the advantage in terms of morality but minus the tradition of rationality, although capable of giving birth to a tough personal morally, but intellectually weak. Instead, the College has the hallmarks of a side of rationality and the 
enrichment in the field of skill, but minus the enrichment of morals. Higher education only produces a smart man,but less have ethical and moral sensibilities. [2]

Based on this development of pesantren in college to find a place that allows generating intellectual capital and also a superior character and UN-Islamic.[3] The development of Islam Indonesia adult institute shows that Islamic education still exists amid change. Boarding, along with madrasah and Islamic school, continues to grow. The interest of the community to send their children to Islamic educational institutions also remained strong, even increased. The case of the boarding school could be one illustration is interesting in this regard. This is the oldest Islamic institution is proven to have the high endurance to still exist in the midst of social change-religious Muslim Indonesia. [4][5][6][7][8][9]

How can expect the presence of quality output if the education surroundings do not give the mainstream for it? Whereas, if a positive student intellectual capital is able to be developed to the maximum, will encourage the growth of critical power, creativity, and productivity of students in the face of life and living now and in the future.

Based on such research will reveal the boarding school in his role in character education and develop student intellectual capital at the Al Furqon Ponorogo. How an intellectual capital developed in a boarding school student Al Furqon Ponorogo. Brontis stated that intellectual capital (intellectual capital) is composed of three components namely (1) Human capital: the knowledge and skills of individuals; (2) Structural Capital: internal processes and information that are the property of the organization; and (c) Relational Capital: the organization has relationships with its stakeholders. [10]

The question of the Islamic College, when Islamic students faculty input very varied competencies, to be tough in the formation and determination of standard output competencies. This can be a problem for the users of graduates because the input of its kinds ability to make trouble in the process and generate competencies variation anyway so that despite having a diploma and of equal value in the same program of study competencies can occur each foreign individual is much different. Therefore, one of the bids could be developed at the Islamic College in Indonesia to ensure the quality of graduates is the dormitories at a boarding school for all courses, so the process more and minimize disruption the negative environment, as well as minimize wasted time without the obvious productivity.

Pesantren Al-Student Furqon pioneered in order to improve the quality of graduates Prodi PAI and PGMI Muhammadiyah University of PonorogFo i.e. become a teacher plus i.e. plus haafiz Qur'an 30 juz, plus adequate Islamic insights, as well as strengthening the science tools Arabic, French, United Kingdom, public speaking and public relation, as well as entrepreneur. The uniqueness of the others: with a short time, the students in boarding schools has significant intellectual development, and also the unique though not saturated each day memorizing the Qur'an and various other material. They are active hosts scientific study with bringing in various figures and leading scientists.

Based on the things above, so this research will reveal the boarding school in his role in character educationf and develop student intellectual capital at pesantren Al-student Furqon Ponorogo. Chief cope with Burnout the students in Mahad Aly Al Furqon Ponorogo.

Research Methodology

This research is the research field. The study was done by selecting the Students University of Muhammadiyah Ponorogo residing in boarding students are purposive. Through field research approach of digging in a field data by means of observations involved and interviews.[9] 
In order to improve our research results, then used the approach of Phenomenology, which seeks and enter into the world of the meaning of the conception in the individual or group who then impacted in the form of the phenomenon. [11]

The values in the experience and their lives will be excavated and described "as is" without using the views already understood researchers. Methods of analysis used are descriptive analysis i.e. analytic performed well in the field (within the site, in the field) and after leaving the field.

\section{Result and discussion}

Pesantren Al Furqon aims to print teachers graduates holders (S-1) plus da'i who excelled in the mastery of the Arabic language, and Tahfidz Islamiyah Dirasah Al Qur'an as capital of da'wah in the community. Character education and development of intellectual capital at Pesantren Al Furqon Ponorogo are supported by (1) infrastructure and funding support. Mahad Aly Al Furqan is located in JL. Tirtotejo 16 Cokromenggalan Ponorogo. The location is very strategic in urban centers, Ponorogo. Means of supporting infrastructure repair in the development of character education and capital among them endorsed intellectual scholars the mosque, a dormitory, a Hall, classroom, laboratory, library and gazebo in Arabic and the language of the United Kingdom.

Boarding high university development in accordance with the directions of the development of Islamic College. That the purpose of established Islamic College originally encouraged by several goals, namely: (1) to carry out the assessment and development of Islamic studies at a higher level in a systematic and movement; (2) to carry out the development and improvement of the Da'wah Islamiyah Islamic, and (3) to conduct production and clerical cadre recruitment and religious functionaries, in various areas of life.If you take the historical perspective in that boarding school students, constitute a model answer to realize the higher Islamic university ulama cadre recruitment at once the embodiment of development integration and interconnectivity of Science [12] or in another term for Islamization. [13]

Islamic higher education was able to produce a generation that excels on the side of morality, intellect, and skill. This, according to what was done by the University of Muhammadiyah Ponorogo which build cooperation with Mahad Aly Al Furqon Ponorogo in shaping students ' pesantren.

College and boarding school has the same cultural roots, i.e., as an institution is only different in their surroundings. If College and boarding school can be integrated into an integral context, then the educational system or model allows as one answer to the integration of the science that combines the power of high ratio of thinking in science produced have the morality or ethics of the high noble in relationships with God, self, others, and the universe. Plus its also notable alumni have reliable skill competencies as experts that can be transformed to order the life of the people and the Nations of the civilized.

Students who are not traveling at Pesantren Al Furqon provide adequate boarding place, tuition fee and living expenses financed from the funds of the Charity and the donor of the Infak within and outside the country.

The system makes the students more of a focus for self-development in preparation to become a teacher himself at the same time the Dai Hafez al-Quran, having adequate insights Islamiyah, mastering communication adequate Da'wah, Arabic-language English. The structure of the habitus of the above makes the students more focused in carrying out studies and educate their characters for the disciplined, punctual, responsible, legitimate dressed, 
clean and neat as mirror modern boarding school. Boarding school students proved to be capable of delivering a student who is obedient to God, both to fellow human beings, and nature.

When compared to students of the University of Muhammadiyah Ponorogo have significant differences. Among them is if the nonstudent ma'had most of their clever discuss, debated but still less orderly worship like prayer in Congregation in the mosque, reading Qur'an, only a small portion of that master of science and Arabic language tools the United Kingdom. In part, they spent time in the stall and a variety of activities that are less useful. While students in the dorm, for having created the rules and agreements as well as the statement to be ready to obey the rules and conditions of the boarding school, then college students tend to be under control and grow into a noble character, private master sufficient scientific knowledge including Arabic and the language of the United Kingdom.

Pesantren Al Furqon in coaching student use to live in the dorm.Itis aimed at creating maximum learning, character education with minimizing negative influences of the outside world and the effectiveness of the construction in the form of the running system of boarding school. During this time the students who are not residents, it is very difficult knowledge ensures the quality, including the difficulty of teaching the Arabic language to advanced, because the environment is less supportive, when in boarding school student, read-write Quran Islamic Faculty Alumni Muhammadiyah University of Ponorogo reliable, tahfizh 30 juz, became its own bargaining power for users. Their competencies are observable in the Islamic insight (tsaqofah Islamiyah), the ability of the Arabic language and Islamic boarding school students because the structure of the system running the support programs like this. The commitment of students to study in earnest. The system affects the habitus intellectual capital in shaping student in pesantren Al Furqon Ponorogo that when students will enter the program at the Ma'had is preferred to the candidate who reallyhas a commitment in earnest to study at Pesantren Al-Undergraduate teacher training Faculties and Furqon Islamic Muhammadiyah University of Ponorogo. In addition to this, the next test attempted by those who already have a rote juz amma. The students who have passed the test must sign the agreements and statements to keep all the rules of the boarding school seen and agreed by parents with brought Pesantren Al Furqon so hopefully not happen communication barriers between the Pesantren Al Furqon student guardians and parents as well as being able to support the process of character education and development of students ' intellectual capital.

Terms of standardizing read wrote the Qur'an. Terms of replicated program tahfidhul the Qur'an in boarding school Student Al Furqon Ponorogo for all new students before learning to memorize the Qur'an, they should be able to read the Qur'an properly and correctly and smoothly, so as to ease the process memorize Qur'an. For students who could not read the Qur'an smoothly, then held learning reading Qur'an until the students fluently read and could carry out the process of tahfidzul of the Qur'an. Evident from the stage, is running read very visibly in preparation at pesantren Al Furqon, also developed a system to keep the character of the education system and the strict rules in the boarding school.

Memorizing the Qur'an and the Sunnah and is obligated to carry out the ritual. Every day starting at 03.00 BST the students raised to praying tahajud, then they start to memorize the Qur'an until dawn. After they carry out prayers in congregation, student habitual to continue muraja'ah to Ustadz until $05.30 \mathrm{pm}$. This provides an environment that gave birth to the culture to obey God with the culture night tahajud prayers, wakes, doing read al-Quran, mura'jaah, and prayers in congregation, as the process of the formation of the Islamic character and the integration of science to landscape practice in everyday life.Strategies for 
creating passion in memorizing, they always are given motivation by the ustadz and ustadzah. When you have not memorized any penalty, but the ustadz gives motivation to them.

Based on this pattern, the intellectual capital of its main student evolved in more memorizing accustomed to memorizing the Qur'an, Hadith, or material that they read more easily memorized.

5.30-7.00 is required for sports, for losing fatigue or Burnout in their activity at Ma'had ' in addition to maintain health and facilitate blood circulation in the body so that students are not subjected to a constraint in Hafez Al-Qur'an.

07.00-08.00 self-clean and breakfast when not Monday and Thursday. When the Monday and Thursday are obliged to carry out fasting on Mondays and Thursdays as habituation building ruhiyah (spiritual) students so that they are increasingly committed to God Almighty and train their soul to care about the poor who lack as a form of the formation of character to a fellow human being.

08.00-09.00 GMT conditioned (habituation) in the form of Duha prayer. After orderly praying Duha, activity subsequently breaks briefly to prepare for entering the College curriculum learning appropriate courses taken or additional material dirasah Islamiyah be aqidah Islamiyah, the Arabic language, Fiqh, Usul Fiqh. This material is usually given at 09.00-15.00 GMT[14].

On 15 at 15:00.30 the students praying ' ASR and execute muraja'ah to ustadz. At 17.00 muraja'ah terminated then clean you, pray Maghrib and dinner, then take a break for a bit waiting for the ' Isha ' prayer'. After they continued with the ' Isha ' prayer in kultum passes scheduled to train their intellectual capital in particular practices directly to call people in the form of kultum. After Isha ' they are memorizing the Qur'an until $21.00 \mathrm{pm}$.

Based on the abovementioned things that habituation in character education and development of students ' intellectual capital and the moral and religious atmosphere is scheduled with strict and regular habit, which forms the students to carry out any day, and eventually became a regular. So intellectual capital as stated in the Brownie i.e. Human Capital: students have knowledge and skill individually. In the structural capital i.e. internalization of the values, experiences, and activities tahfizh pesantren became the intellectual capital for the students at the boarding school.

Scientific study at Pesantren Al Furqon held once a month, by bringing leading speakers. With the hopes that the students of al-Furqon has enough scientific insights and can face the challenges of the times. This study used to establish relations with the scholars and scholars of Muslim cooperation at various colleges and boarding schools in Ponorogo. These activities develop a capital relationship students i.e. students having relations with stakeholders with the da'i, lecturers, society of the stormy night regions and disciplines.

These scientific review activities, organized and run by students at the Al Furqon, including $\mathrm{MC}$, the selection of themes and the election of the speaker. With the scientific study of the material that has been given in pesantren, students feel an awful lot got science and wider insights about Islam so that the competencies themselves about intellectual capital more comprehensive examination the use of a variety of perspectives.

Based on the structure of the habitus that is in boarding school Student Al-Furqon intellectual capital development support agency i.e. students proved the existence of their awareness to review various sources of Islamic teachings and knowledge, they active hosts and follow the study, as well as more critical, boldly argued against the teachings of Islam with their updating cross check sourcebooks, book, opinions from various book and cross the book sources. 
Students in Mahad trained to preach directly in the community. At the boarding school trained and conditioned to read, then delivered a sermon and kultum. In addition, students pitch in 2 times a year in the community in the form of charity program such as Eid al-Adha, care about natural disasters and so forth so that their relationship capital against welldeveloped stakeholder made experiences in transform yourself in life now and in the future.

Based on the experience of the students in General that saturation often occurs at boarding school, because the material is monotonous and there is no entertainment that reflection mind the santri. In pesantren Al Furqon already anticipated way overcome the saturation of each student, for their male students every morning at $05.30-06.30$ are required to run in the morning and walk, if they get out of the dorm and a breath of fresh air as well as diaphoretic their bodies more fresh and relaxed. As for the Sorority, they sport martial arts, archery, cycling. When Sunday, the students there are entrepreneurial activities. The results of character education and development of students ' intellectual capital at Pesantren Al Furqon Ponorogo has led to encouraging results. That memorizing in 2 years has achieved an average of 20-30 juz, insight, a sense of the broad Islamic trust yourself in public speaking primarily in filling out the study, and both kultum khutbah lecture presentations have been good.

This boarding school model more effective in character education and development of students ' intellectual capital so that it is capable of producing quality graduates for Islamic education. Student character Results formed,i.e. disciplined, well-mannered, polite, respectful and worship, live clean, bold, responsibility, independent, caring, helpful, diligent and tenacious. Boarding students are a very urgent model developed in various PTAI in Indonesia or the international world.Analyzed by the boarding students at the model Al Furqon Ponorogo that habitus that awakened during boarding school Al Furqon have shaped the character of students and develop the intellectual capital that rapidly. With a positive culture that is developed, and the lack of influence from outside, including strict rules as well as the obvious target capital competence student self-esteem, competence in understanding and management system as well as Islamic boarding school in the life and relationship with stakeholders can be achieved with either.

\section{Conclusion}

Character education and development of students ' intellectual capital at pesantren $\mathrm{Al}$ Furqon Ponorogo can be inferred that the habitus that awakened during boarding school Al Furqon have shaped the character of students and develop intellectual capital rapidly. With a positive culture that is developed, and the lack of influence from outside, including strict rules as well as the obvious target capital competence student self-esteem, competence in understanding and management system as well as Islamic boarding school in the life and relationship with stakeholders can be achieved with either. Thisis supported by the structure of the system of boarding school students (1) infrastructure and adequate funding. (2). Mukim in the dorm (3) statement of commitment of the parents and students to learn in earnest (4). The terms standardization Read Wrote the Qur'an in Early Entry (5). Memorizing the Qur'an and the Sunnah and is obligated to carry out the ritual. (6) A scientific study (7) Preaching in the community directly. The seven models habitus that support character education students and students ' intellectual capital.

The strategy of overcoming the Burnout of college students are entrepreneurial; sports activities run in the morning, biking, farm, bazar, contest, outbound, charity program, camp, and life skill as well as supported, variation food menu, the cost of living is provided people satisfied boarding school while intellectual capital development student in pesantren Furqon 
Ponorogo have met the target of memorizing in 2 years reaching 20-30 juz. The development of critical power and excellence in public communication, independent in a hold and draw up the agenda and themes of scientific activities. Liveliness issued opinions in class discussions, presentations, as well as filling the Islamic activities in the community.

\section{References}

[1] O. Azam, S. Hussien, and S. A. Ismail, "Islamic integrated education system model in the Malay archipelago : Implications for educational leadership," Intellect. Discourse, vol. 1, no. 4, pp. 203-226, 2017.

[2] H. S. Zainiyati, "Model Kurikulum Integratif Pesantren Mahasiswa dan UIN Maliki Malang," Ulumuna, vol. 18, no. 1, pp. 139-158, 2014.

[3] M. S. Kahar and D. Pabalik, "Profil Pendidikan Karakter Mahasiswa Non Muslim dalam Implementasi Al-Islam dan Kemuhammadiyahan," Al-Hayat J. Islam. Educ., vol. 2, no. 1, pp. 79-88, 2018.

[4] Z. Nur'aeni, "Darut Tauhid: Modernizing a Pesantren Tradition," Stud. Islam., vol. 12, no. 3, 2005.

[5] A. Darmawan Achmad and S. Nurjan, "Attachment as Character Education in Boarding School," in Proceedings of the International Conference on Ethics in Governance (ICONEG 2016), 2017.

[6] E. Sari, "The Role Of Environmental Management Education In Islamic Boarding Schools (Pesantren) In Preventing The Radicalism Of Students In Indonesia," Int. J. Educ. Res., vol. 4, no. 7, pp. 401-416, 2016.

[7] A. S. Chalim, "3D IPEA Model to Improving the Service Quality of Boarding School," Asian Soc. Sci, vol. 12, no. 7, p. 119, 2016.

[8] M. E. Sari, "The Role of Learning Management of Islamic Boarding School (Pesantren) in Improvement of Their Students Religious Tolerance in West Java Indonesia," Int. J. Innov. Appl. Stud., vol. 19, no. 1, pp. 24-32, 2017.

[9] J. Bell, Doing Your Research Project: A Guide for First-Time Researchers. UK: McGraw-Hill Education, 2014.

[10] A. I. Ferreira, "Intellectual capital: perceptions of productivity a and investment," Rev. Adm. Contemp., vol. 15, no. 2, pp. 249-260, Apr. 2011.

[11] G. W. F. Hegel, "The Phenomenology of Mind," Nature, vol. 130, no. 3281, pp. 420420, 1932.

[12] M. A. Abdullah, "Religion, Science, and Culture: An Integrated, Interconnected Paradigm of Science," Al-Jami'ah J. Islam. Stud, vol. 52, no. 1, p. 175, 2015.

[13] N. H. M. Nawi, "Kesinambungan Dan Sinergisme Konsep Kesepaduan Dan Islamisasi Ilmu," E-Journal Arab. Stud. Islam. Civiliz., vol. 2, pp. 60-68, 2015.

[14] A. Ikhwan, "MANAGEMENT OF LEARNING ASSESSMENT USING CURRICULUM 2013 (CASE STUDY IN ISLAMIC PRIMARY SCHOOL (MI) MUHAMMADIYAH 5 WONOASRI PONOROGO - EAST JAVA - INDONESIA)," MUADDIB Stud. Kependidikan dan Keislam., vol. 08, no. 02, pp. 108-123, 2018. 